\title{
A Study on Teacher Strategies in Teaching Speaking and Reading Comprehension Skills: A Case Study at SMAN 8 Mataram
}

\author{
Ira Sariyah Hidayati* \\ Postgraduate English Study Program \\ University of Mataram \\ Mataram, Indonesia \\ irasariyahh96@gmail.com
}

\author{
Muhammad Amin \\ Postgraduate English Study Program \\ University of Mataram \\ Mataram, Indonesia \\ aminmuhammad@unram.ac.id
}

\author{
Yuni Budi Lestari \\ Postgraduate English Study Program \\ University of Mataram \\ Mataram, Indonesia \\ lestari2006@gmail.com
}

\begin{abstract}
Speaking and reading are two important skills in learning English. Various strategies in teaching speaking and reading comprehension are needed to facilitate students to achieve in these skills. This paper discusses the strategies of an English teacher in teaching speaking and reading comprehension skills based on a case study conducted at SMAN 8 Mataram. The study involved one English teacher and 30 students as participants of the study. The data were collected by using classroom observations to directly see the teaching process in the classroom. Interview with the teacher was also employed to obtain information on their reasons of implementing the strategies. Meanwhile, questionnaires were given to the students to identify their responses towards the strategies used by their teacher. The data were analyzed by using the following procedure: (a) identify the strategies used by the teacher in the classroom (b) identify the students' response toward the teacher strategies in teaching speaking and reading comprehension skills. The study found that there were various strategies used by the English teacher in teaching speaking and reading comprehension skills. In teaching speaking the teacher used these strategies: roleplay, drilling and creative tasks. In teaching reading comprehension teacher used strategies in three reading stages: pre-reading, while-reading and post-reading stage. Students positively responded to the strategies and they believed that the strategies helped them develop speaking and reading skills.
\end{abstract}

Keywords: teacher strategies, speaking, reading comprehension, a case study.

\section{INTRODUCTION}

English is a compulsory subject at every school in Indonesia. Whether it is taught at international schools, public schools or private schools, English subjects exist at every level of education in Indonesia. However, the application of English learning in some schools is still considered less than optimal. This is evidential in the students' disability to use English, although many of them have studied it for six or more years. In addition, based on some experience in teaching and learning
English in schools, the teacher's lack of knowledge of the strategy or learning method in delivering learning material to students, sometimes teachers still often use traditional learning strategies. Teaching English in a rigid manner is just like teaching grammar rules and memorizing tense formulas without teaching how to use them when speaking.

The lack of reading interest of Indonesian students also affects the ability of students to understand a reading text. Therefore, teachers play important roles in invoking this interest. Teachers must find suitable strategies for their students. Because the teacher takes a very important role in a learning activity where the success or failure of a learning activity depends on how they deliver the materials. Teachers must pay more attention to the needs of students and be able to motivate them. Teachers must also be able to encourage them to use English.

One of the learning strategies that must be considered is the strategy in teaching speaking and reading comprehension skills, considering speaking and reading as two important skills in learning English. Reading skills are very important for students because with reading skills students can develop other skills such as speaking and writing. Reading is a key factor in language learning. One important idea for developing reading and speaking skills is to use language for learning and communication. Reading can play a big role in successful language learning. That can develop speaking skills, students who read a lot have better reading skills [1]. In teaching and learning activities, the strategy used by the teacher in teaching is an important factor, where the learning strategy affects the achievement of the learning objectives expected or planned by the teacher. There are several definitions of learning strategies. Strategy comes from the word "Strategia" which comes from Greek. According to Richards et al. [2] strategy is a set of procedures used in achieving goals in learning, thinking, and teaching. Trianto [3] defines strategy as a direction of actions 
to achieve the formulated goals. From the definitions above, strategy can be concluded as a created plan to achieve the goals.

One of the goals of learning a language is that we can use the language, both orally and in writing. The ability to use it is a measure of success in learning a language. Speaking is one of the skills in using English that students must learn and master. Speaking is an activity in communication of how to convey meanings. According to Nunan [4]"Speaking is a productive aural/oral skill and it consists of producing systematic verbal utterances to convey meaning". Furthermore, Chaney [5] states that speaking is a process of expressing or conveying meaning in several situations which is carried out verbally or non-verbally. Then according to Bygate [6] speaking is a process of producing auditory signals to produce different verbal responses to listeners. Furthermore, Harmer [7] states that speaking have many different aspects two of the is accuracy, this is involving the use of vocabulary, grammar and the pronunciation correctly, it is practiced through the guided activity, and the last one is the fluency it is seen as the ability to keep going when speaking spontaneous, this is seen from communicative views.

According to Alderson [8] reading is an activity involving interaction between a reader and a reading text. According to him, during a process of reading the reader thinks about what they are reading, identifies the meaning of the text, and connects information in the text. Furthermore, Harmer [9] stated the reader will get chances to learn about vocabulary, grammar, punctuation and to create sentences, paragraphs and texts though the reading activities. Nunan defines reading as a process whereby the reader combines information from the text with their own background knowledge, and build network of meaning from the text. Reading activities are carried out to increase intellectual potential, namely knowledge, understanding, application, analysis, synthesis and evaluation. Reading skills need to be possessed because most of the knowledge is presented in reading texts, even though there are many other sources such as YouTube, however, knowledge can only be obtained from original sourcesthrough reading them.

Reading comprehension is an important skill in English. Reading is an activity to get information from a reading whether it is from books, electronic media, a reading text, newspapers and the like. According to Snow et al [10] reading comprehension is the process of explore and construct the meaning simultaneously by interaction and involvement with written language. They added that in reading comprehension there are three elements, namely readers, text and reading activities are the goals or processes and consequences associated with the act of reading. According to Brown [11] a reader can understand what $\mathrm{s} / \mathrm{he}$ is reading because he has the ability to incorporate the information he gets from the past into several aspects related to his knowledge, experience, culture and emotions. Reading skills do not just exist or are owned by an individual naturally, but they are obtained through the learning process. In the school environment, the ability to read needs to be taught by teachers through various approaches and methods.

SMAN 8 Mataram is one of the public schools in the city of Mataramwhere English has been taught as one of the compulsory subjects. At SMA 8 itself there are two types of English subjects, namely compulsory English subject and English as a specialization. In this study, the teachers' strategies in teaching speaking and reading comprehension skills in both types of subjects are identified. This is to find out what strategies are applied by the teacher in teaching and learning activities and whether the strategies applied by the teacher are in accordance with the needs of students and can motivate students when learning English takes place.

\section{METHODS}

This study used qualitative case study designbecause it observed strategies in teaching speaking and reading comprehension skills and identified students' responsestowardd the strategies.According to Cohen and Manion [12], a case study explains a phenomenon by studying one example of the case deeply by observing the characteristics of the unit of individual, group, class, school or community. This study observed the teachers' strategies in teaching speaking and reading comprehension skills. This study conducted at SMA 8 Mataram. The participants were a grade-10 English teacher and 30 students. The teacher and student participants were recruited from the only grade-10 English class at the school. Data were collected by means of classroom observation, interview and questionnaire. Nonpsrticipant classroom observation was used to examine directly the teaching and learning processes in the classroom. Interviews with the teacher were conducted to examine the rationale behind the choice of strategies. Questionnaires to the students were distributed to identify their responses towards the teacher's strategies.

\section{RESULTS AND DISCUSSION}

Data analyses indicate patterns in teacher's strategies and the students' responses to them when the former teach speaking and reading comprehension skills. 


\section{A. Teacher strategy in teaching speaking skill}

One of the factors that influence the success of a learning activity is the teaching strategy used by the teacher in delivering learning materials. In this case the teacher plays an important role in designing and implementing the strategy so that the expected learning objectives can be achieved. The learning strategy in question is the teacher's way of delivering learning material so that the learning process runs as expected. There are some data Based on the interview with the English teacher of SMAN 8 Mataram, in teaching speaking teacher used some commonly strategies and this is the data according to the interview with the teacher, and her opinion about the implementation of those strategies.

Based on the result of data observation, there some strategies that used by English teaching teacher in teaching speaking skill, among of the strategies are drilling, role play, and creative tasks. Drilling is a common strategy in teaching speaking, in using this strategy the teacher writes the sentence in English then explains the function of the sentence then says it, then the teacher asks the student to repeat what he said several times. Then in implementing the role play strategy the teacher asks students in groups to play several roles in the conversations that are in the textbook material. based on teacher opinion she used drilling because she believes that, through repetition student Will practice their speaking appropriately and students Will remember the correct form of sentence that they learn. In using Creative task in her teaching activity teacher use kind of creative task such as storytelling which, she believes that with using story telling can practice students speaking skill based on the real context, besides that it can improve student's confidence in using English while speaking, teacher ask the students to tell anything about their activities such as about their idol, holiday and so on. And by using role play strategy teacher believe it will give the students opportunity to practice their speaking ability with their friends, they can also share their opinion with each other about the Topic being discussed, and also, they can correct their speaking each other. With the implementation of this strategy, students are also accustomed to using English and make them not stiff when it comes to speaking in English.

\section{B. Teacher strategies in teaching reading comprehension skill}

From the data findingin teaching reading comprehension teacher used strategies in three reading stages: pre-reading, while-reading and post-reading stage. Pre-reading stage is the activity aims to prepare readers to understand the contents of the reading text through initial knowledge and predictions so that readers can understand the reading text quickly. During this activity, reading aims to focus on the content of the reading and analyze the content of the reading text. The activity that is carried out before doing the reading activity is to choose a reading text, in choosing this reading text the teacher must choose the right reading text that is in accordance with the conditions and ability levels of the students.

Based on the results of classroom observations, the teacher uses reading texts contained in textbooks, besides that the teacher selects reading texts from several sources from the internet, to suit the students' abilities. The reading text used by the teacher is mostly descriptive text or text that provides information that is familiar or familiar to students, this is done by the teacher so that students can understand the reading quickly, then the teacher provides a simulation so that students observe the title and illustration of the attached image. In the reading text, then the teacher asks questions related to the reading topic, makes predictions related to the reading text. Then in the stages while-reading it is a reading activity itself, at this stage the teacher asks students to read the reading text then the teacher and the students summarize their reading results then ask the students to ask about things they have not understood in the reading text. the last one is post-reading which aims to respond to tests that have been read, in this section includes activities such as asking, predicting and concluding, the teacher in this section asks students to predict the results they have gotten so far from the reading activities carried out, the teacher also asks about the related reading text, then both concludes with the students what the core and information is conveyed from the reading. Then the teacher links the information from the reading with some of the teacher's personal safeguards.

By using pre-reading while-reading and post-reading strategies in teaching reading comprehension skill, based on teacher opinion, it will build student curiosity and it Will make students critically thinking about the reading material that they study and they are being discuss.

\section{Students' responsestowardsthe teacher's strategies}

Based on the questionnaire data observation that given to 30 students of tenth grade, it can be concluded that the dominant of the students said that the strategies that applied by their teacher in the classroom can help their speaking and reading comprehension skills, it can help them to develop their speaking skill, but some of the students said that they feel bored when the teacher use repetition in teaching them speaking skill. It can be concluded that the strategies implemented by teacher give benefit to help the students in their speaking and reading comprehension. It can motivated 
them and reduce their anxiety in speaking English. Almost students give the positive response.

\section{IV.CONCLUSION}

Based on the finding and discussion above it can be concluded that the teacher has used various learning strategies in the learning activities of speaking and reading comprehension skills. Based on the data from the interview with the teacher, some of the reasons for the teacher applying various strategies in teaching speaking are so that students do not feel bored during the lesson; it can also motivate students in learning speaking and reading comprehension. Finally, based on questionnaires data from students, the strategies used by their teachers can help them achieve learning goals. Based on classroom observation, several other factors that affect students' performance in speaking and reading comprehension skills are students' lack of confidence in their abilities or students' reluctance to take part in learning activities or activities.

\section{REFERENCES}

[1] Mart, Tughul et al. Developing Speaking Skills through Reading. International Journal of English Linguistics. Vol.2 No. 6. 2012

[2] Richards, Jack C., and Theodore S. Rodgers. Approaches and methods in language teaching. Cambridge university press, 2014.

[3] Trianto, M. Pd. "Mendesain model pembelajaran inovatif-progresif: Konsep, landasan dan implementasinya pada Kurikulum Tingkat Satuan Pendidikan (KTSP)." Jakarta: Kencana 2010.

[4] Nunan, David. "Practical english." Language Teaching. New York: Mc Graw Hill 2003.

[5] Chaney, Ann L., and Tamara L. Burk. Teaching Oral Communication in Grades K-8. Allyn and Bacon, Order Processing, PO Box 11071, Des Moines, IA 50336-1071, 1998.

[6] Bygate, Martin. Speaking. Oxford university press, 1987.

[7] Harmer, J. The Practice of English Language Teaching. The 3th Edition. Longman: London and New York. 1991

[8] Alderson, J Charles. Assessing Reading. Cambridge: Cambridge University Press. Brown, Douglas. 2000

[9] Harmer, Jeremy. The practice of English language teaching. longman, 2001.

[10] Snow, Catherine. Reading for understanding: Toward an $R \& D$ program in reading comprehension. Rand Corporation, 2002.

[11] Brown, H.D. Teaching by Principles: An Interactive Approach to Language Pedagogy. Second Edition. New York: Pearson Education Company. 2001

[12] Cohen, L., and L. Manion. "Research methods in education 4th edition Routeledge." 1994. 